\title{
ANALYSIS OF OIL PALM AND RUBBER PRODUCTION TO GROSS DOMESTIC PRODUCT OF TEN DISTRICTS IN WEST KALIMANTAN BY PANEL REGRESSION
}

\author{
Evy Sulistianingsih ${ }^{1}$, Mariatul Kiftiah ${ }^{2}$, Dedi Rosadi ${ }^{3}$, Heni Wahyuni ${ }^{4}$ \\ ${ }^{1,2}$ Department of Mathematics, University of Tanjungpura, Pontianak, Indonesia \\ ${ }^{3}$ Department of Mathematics, Universitas Gadjah Mada, Yogyakarta, Indonesia \\ ${ }^{4}$ Department of Economics, Universitas Gadjah Mada, Yogyakarta, Indonesia \\ *Corresponding E-mail : evysulistianingsih@math.untan.ac.id
}

\begin{abstract}
West Kalimantan is a province in Indonesia that has a prominent role as oil palm and rubber producer. However, it is inevitable that as oil palm and rubber production plantation have developed, environmental and social problems as well happened nearly the plantation areas. For that reason, this research was conducted to analyse the relationship of oil palm and rubber production to the welfare of inhabitants in ten districts in West Kalimantan, namely Sanggau, Sintang, Sambas, Ketapang, Bengkayang, Landak, Kapuas Hulu, Melawi, Sekadau and Singkawang. The welfare of the inhabitants in this case was measured by Gross Domestic Product of every districts. According to the result, it can be deduced that Fixed Effect Model with adjusted determination-coefficient 0,76 , is the best model to analyse this case. In addition, the research also concludes that oil palm and rubber production are statistically significant to GDP of the districts. So that, even though oil palm and rubber production tend to give negative impact to the environment but the result of this research shows that oil palm and rubber production donate positive influence to increase the welfare of the inhabitants.
\end{abstract}

Keywords: Longitudinal, Breusch-Pagan, Cross-Section Weight

DOI: https://doi.org/10.30880/jtmb.2018.05.03.001

\subsection{Introduction}

According to Indonesian Central Bureau of Statistics of West Kalimantan (BPS of West Kalimantan) (2014), West Kalimantan's Gross Domestic Product (GDP) is ranked 22nd out of 33 provinces in Indonesia. Meanwhile, West Kalimantan had approximately 8,3 million hectares of forest area (The Ministry of Forestry of Indonesia, 2014). This number stood the province on the fifth place among 33 provinces in Indonesia in terms of the wide of forest area. In addition, West Kalimantan has a large area of oil palm and also rubber plantations which is divided become small holder estate and large estate. For small holder estate, production of oil palm plantation increased significantly from 334.615 tons in 2006 to 339.866 tons in 2014 while production of rubber plantation raised approximately 370.000 tons over the period of time (BPS of West Kalimantan (2015)). Those evidences have shown that there is an unbalanced situation between GDP and the real condition of natural resources in the province.

On the other hand, there were many researches that summarized negative effects which are caused by development of either oil palm or rubber plantation. Wicke et al (2011) reported that land use change (LUC) caused by oil palm production happened in Indonesia. Then, Jaenicke et al (2010) reported that oil palm plantation have caused severely degradation of forest especially for peat-swamp forest in Kalimantan. The negative effect of the plantation also was reported by Rist, Feintrenie, and Levang (2010). They founded that there were some conflicts between inhabitants and large estate plantation. The conflicts happened because of lack of transparency, the absence of freedom, and unequal benefit sharing. Because there were negative impacts 
reported previously, analysis of rubber and oil palm plantation (in this case is production of both plantation) for GDP become important aspect, especially for West Kalimantan as a producer of those commodities.

Some scientists have carried out several research of some aspects that can give a contribution to GDP. Those aspects are oil palm plantation and rubber plantation.

Mara and Fitri [2013] evaluated a role of oil palm plantation in order to increase economy of villages in Jambi, a Province in Indonesia. According to the research, it can be concluded that oil palm plantation can increase GDP of the villages. Furthermore, scores of multiplier effect of oil palm commodity for each village taken as research sample were between 1.08 and 1.97.

Then, Sanggin and Mersat [2012] conducted and observed impacts of oil palm plantation organised by Sarawak and Land Consolidation and Development Authority (SALCRA) to prosperity of land owner community nearby the plantation. The research summarized that oil palm plantation can raise the community income.

Contribution of oil palm plantation to GDP was also analysed by Supriadi [2013]. The research investigated a relationship between oil palm plantation and economical aspect in Sambas, a district in West Kalimantan. According to the research, it can be concluded that expansion policy of oil palm plantation in Sambas district can increase well-being of community from 2006 until 2011. In addition, the research also summarised that there was an augment of $3.43 \%$ in Sambas's GDP yearly.

The second aspect, that has been considered to give an influence to GDP is rubber production. Nelonda (2008) analysed commodity of rubber as a subsector plantation toward growth of agriculture sector in West Sumatera. The research concluded that rubber commodity influenced the economic of West Sumatera Province.

Because there were some evidence that oil palm plantation (in this case is oil palm production) and rubber production influenced GDP in other districts in Indonesia. Therefore, this paper intends to analyse relationship between some factors and ten-district's GDP in West Kalimantan, namely Sanggau, Sintang, Sambas, Ketapang, Bengkayang, Landak, Singkawang, Kapuas Hulu, Melawi, and Sekadau by panel regression. This research will analyse district-level data of those factors from 2006 to 2014 derived from Kalimantan Barat dalam Angka published by BPS of West Kalimantan (2009-2015).

\subsection{Panel Regression}

A panel data set is a combination of time series and cross section data. Meanwhile, a regression model used to analyse panel data is called by panel regression model [Rosadi, 2010]. Hsiao [2014] claimed that panel regression model could be more accurate to estimate parameters of a regression model. This accuracy is caused by a large number of data points in panel regression model, so that there is an increase of degrees of freedom of the model. Then, the model also can decrease the collinearity among independent variables.

Baltagi [2005] stated that a panel regression model (PRM) can be written as follows

$$
z_{i t}=\alpha_{i t}+\beta_{i t} x_{i t}+\varepsilon_{i t}, \quad i=1,2, \ldots, N ; t=1,2, \ldots, T
$$

where $z_{i t}$ is dependent variable, $x_{i t}$ is independent variable, and $\varepsilon_{i t}$ is the error term, uncorrelated with $x_{i t}$, with mean zero and constant variance $\sigma_{\varepsilon}^{2}$. In addition, $\alpha_{i t}$ is a scalar and $\beta_{i t}$ is regression coefficient, slope. On equation (1), the subscript $i$ denotes the cross section dimension while $t$ symbolises the time series dimension.

Baltagi [2005] also argued that PRM concentrates to control the impact heterogenity that cannot be unobserved. This way was executed for getting valid inference on $\beta_{i t}$. For instance, unobserved heterogenity in a linear regression model is assumed as an individual spesific and time invariant. So that (1) can be formulated as

$$
z_{i t}=\alpha_{i}^{*}+\beta_{i} x_{i t}+\varepsilon_{i t}, \quad i=1,2, \ldots, N ; t=1,2, \ldots, T
$$


The parameters $\alpha_{i}^{*}$ and $\beta_{i}$ for different cross sectional units can be different, eventhough both of them stay constant over time. Then, sampling distribution can seriously mislead the least square regression of $z_{i t}$ on $x_{i t}$ when all of NT observations are utilised to estimate (3) as follows [Hsiao, 2014]

$$
z_{i t}=\alpha^{*}+\beta x_{i t}+\varepsilon_{i t}, \quad i=1,2, \ldots, N ; t=1,2, \ldots, T
$$

Generally, there are three models that can be chosen to obtain estimators in panel regression, namely Common Effect Model (CEM), Fixed Effect Model (FEM), and Random Effect Model (REM). CEM can be written as (3) where the regression parameters will be estimated by Least Square. In CEM, cross section data and time series are united and considered as one whole observation. On the other hand, Hsiao [2014] stated that FEM can be expressed as

$$
z_{i t}=\alpha_{i}^{*}+\beta x_{i t}^{\prime}+\varepsilon_{i t}, \quad i=1,2, \ldots, N ; t=1,2, \ldots, T
$$

where $\alpha_{i}^{*}$ vary over individuals. FEM, in this research, is assumed that there is no time spesific effects. Meanwhile, REM can be written as (1) but $\alpha_{i t}$ is assumed as a random variable with the expectation $\alpha_{0}$, so that $\alpha_{i}^{*}=\alpha_{0}+\varepsilon_{i}$. Consequently, REM can be written as

$$
z_{i t}=\alpha_{0}+\beta_{i t} x_{i t}+w_{i t}
$$

where $w_{i t}=\varepsilon_{i}+\varepsilon_{i t}$.

There are some statistical tests which are involved to analyse independent variables and dependent variables by panel regression model. Those are Chow Test, Hausman Test and also Lagrange Multiplier Test. Function of the three statistical test was mentioned at Sulistianingsih et all [2017].

Furthermore, panel regression has been utilised prominently to evaluate some cases in numerous journals such as Ayunanda and Zain [2014], Pusakasari [2015], and Sulistianingsih et all [2017]. Those journals will be used to study the methodology in analysis of panel data.

\subsection{Oil Palm and Rubber Production}

BPS-Statistics Indonesia [2016] and Feintrenie et all [2010] argued that Indonesia has been claimed as the world's largest producer of oil palm. Oil palm has a significant impact to economical aspect of Indonesia, because it has been contributed to earn foreign exchange for the country. Then, according to BPS-Statistics Indonesia (2016), total number of oil palm plantation area increased from 9.13 million hectares, in 2011, to 10.75 million hectares, in 2015. In other words, there was an increase about $25.80 \%$ over the five years. Then, in 2015 , production of oil palm in Indonesia reached 31.28 million tons. So, there was a significant augment of the production as $6.85 \%$ from 2014 to 2015. It was about 2 million tons.

West Kalimantan, one of the provinces in Indonesia, was noted as the fifth biggest producer of oil palm in Indonesia [BPS-Statistics Indonesia ${ }^{1}$, 2015]. Its position was situated after Riau, North Sumatera, Central Kalimantan, and South Sumatera. Table 1 shows oil palm production yielded by the ten biggest oil palm producer in Indonesia [BPS-Statistics Indonesia, 2017]

Table 1: Oil Palm Production by Province

\begin{tabular}{llll}
\hline Province & $\begin{array}{l}\text { Oil Palm Production } \\
\text { (thousand tons) }\end{array}$ & Province & $\begin{array}{l}\text { Oil Palm Production } \\
\text { (thousand tons) }\end{array}$ \\
Riau & 8059.8 & Jambi & 1794.9 \\
North Sumatera & 5193.1 & East Kalimantan & 1586.6 \\
Central Kalimantan & 3573.0 & South Kalimantan & 1049.5 \\
South Sumatera & 2821.9 & West Sumatera & 926.6 \\
\hline
\end{tabular}




\begin{tabular}{llll}
\hline West Kalimantan & 2168.1 & Aceh & 896.3
\end{tabular}

On the other hand, besides oil palm, rubber also become a prominent commodity for Indonesia. Nowadays, rubber has significant impact to get foreign exchange because Indonesia's rubber has been exported to many countries in the world such as United States of America, Japan, and China.

Based on BPS-Statistics Indonesia ${ }^{1}$ [2016], Indonesia has become the largest producer of rubber in the world. Meanwhile, position of West Kalimantan in terms of rubber producer in Indonesia was situated at the fifth position. Table 2 lists rubber production yielded by ten provinces in Indonesia [BPS-Statistics Indonesia, 2017]:

Table 2: Rubber Production by Province

\begin{tabular}{llll}
\hline Province & $\begin{array}{l}\text { Rubber Production } \\
\text { (thousand tons) }\end{array}$ & Province & $\begin{array}{l}\text { Rubber Production } \\
\text { (thousand tons) }\end{array}$ \\
South Sumatera & 944.0 & South Kalimantan & 165.1 \\
North Sumatera & 409.8 & Lampung & 130.2 \\
Riau & 322.5 & West Sumatera & 120.0 \\
Jambi & 260.6 & Central Kalimantan & 117.9 \\
West Kalimantan & 233.5 & Bengkulu & 95.8 \\
\hline
\end{tabular}

Because there were a good position of West Kalimantan as oil palm and also rubber producer in Indonesia, these facts more encouraged this research to analyse the relationship between the dependent and the independent variables by panel regression.

\subsection{Methodology}

Data utilized in this research are oil palm production, rubber production and GDP of ten districts namely Sanggau, Sintang, Sambas, Ketapang, Bengkayang, Landak, Singkawang, Kapuas Hulu, Melawi, and Sekadau. This research attempted to analyse district-level data of those factors from 2006 to 2014 derived from Kalimantan Barat dalam Angka that was published by BPS of West Kalimantan (2009-2014).

In Indonesia, oil palm and also rubber plantation are separated become two types namely large estates and small holder estate. Only oil palm and rubber production produced by small holder estates will be analysed in this research. Then, for simplification reason, the variables in this research namely the GDP, oil palm and rubber production successively are simbolised by $z, x_{1}$ and $x_{2}$. Those data are panel data that will be analised by panel regression. Some steps that are included in analyse panel data are written as follows (Ayunanda and Zain, 2014):

1. Analyse the characteristics for independent and dependent variables

2. Check multicollinearity among independent variables

3. Conduct Chow Test, Hausman Test, and Lagrange Multiplier Test

4. Choose the best model among CEM, REM and FEM according to result of Step 3

5. Check variables which are statistically significant at the choosed model at Step 4

6. Conduct Heteroscedasticity Test, Autocorrelation Test, and Normality Test

\subsection{Results and Discussions}

In this section, panel regression will be utilised to analyse two factors which are considered giving influence to GDP of the ten districts. Before analyse the data by panel regression, multicollinearity test was conducted previously to check whether the multicollinearity happens or not. According to the result of multicollinearity test, VIF value for each variable is smaller than 10. So that, there is no multicollinearity between the independent variables.

After ensuring that there is no high correlation between the independent variables, Chow Test was done to evaluate which one is better between CEM and FEM to be used in modelling the 
panel data. Chow Test showed that F-calculated is 173.59 , which is more than F-table with $\alpha=5 \%, 3,95$. So that, it can be concluded that FEM is a better model to use rather than CEM.

After Chow Test, Hausman Test is conducted to examine whether there is a random effect or not in the model. According to Hausman Test's result, FEM is better model than REM. It was shown by chi-square-statistics, 24.087, which is bigger than chi-square table, with degrees of freedom 3 and $\alpha=5 \%, 5.991$.

Next, Lagrange Multiplier Test was executed to check heteroscedasticity in the model. Then, based on Lagrange Multiplier Test, it can be deduced that there is heteroscedasticity in FEM $\left(L M_{\text {hitung }}>\chi_{(0.05,2)}^{2}\right)$. So that, parameters in FEM have to be estimated by cross-section weight.

According to the three test results, it can be concluded that FEM is the best model rather than CEM and FEM. Moreover, FEM for this case can be seen at Table 3 as follows:

Table 3: FEM

\begin{tabular}{lcll}
\hline \multicolumn{1}{c}{ Variable } & Coefficient & \multicolumn{1}{c}{ Variable } & Coefficient \\
\multicolumn{1}{c}{ C } & -8392156 & & \\
\multicolumn{1}{c}{$x_{1}$} & 116.8561 & & \\
Fixed Effects (Cross) & 369.1490 & & \\
Sanggau & & Fixed Effects (Cross) & \\
Sintang & -16347210 & Landak & -3254966. \\
Sambas & -4297198. & Melawi & 2506815. \\
Ketapang & 7832545. & Sekadau & -2829976. \\
Bengkayang & -1811476. & Singkawang & 10287800 \\
\hline
\end{tabular}

Then, based on the results of Heteroscedasticity Test, Autocorrelation Test, and Normality Test, it can be summarized that the FEM fulfilled heteroscedasticity, autocorrelation, and normality assumption. So that, this model can be utilized to describe the relationship between dependent and independent variables used in the model.

Moreover, based on Table 3, it can be deduced that every rise of oil palm production as one ton will increase the GDP about 116.8561 million rupiahs. Furthermore, each increase of rubber production as one ton, it can contribute to raise the GDP, approximately 369,15 million rupiahs. More over, FEM can distinguish effect of every districts, so estimation of GDP for ten districts in West Kalimantan can be written as follows at Table 4

Table 4: FEM for Ten Districts in West Kalimantan

\begin{tabular}{cc}
\hline District & Estimation of GDP \\
Sanggau & $-24739366+116,8561 x_{1}+369,1490 x_{2}$ \\
Sintang & $-12689354+116,8561 x_{1}+369,1490 x_{2}$ \\
Sambas & $-559611+116,8561 x_{1}+369,1490 x_{2}$ \\
Ketapang & $-10203632+116,8561 x_{1}+369,1490 x_{2}$ \\
Bengkayang & $-6650499+116,8561 x_{1}+369,1490 x_{2}$ \\
Landak & $-11647122+116,8561 x_{1}+369,1490 x_{2}$ \\
Singkawang & $1895644+116,8561 x_{1}+369,1490 x_{2}$ \\
Kapuas Hulu & $-2220147+116,8561 x_{1}+369,1490 x_{2}$ \\
Melawi & $-5885341+116,8561 x_{1}+369,1490 x_{2}$ \\
Sekadau & $-11222132+116,8561 x_{1}+369,1490 x_{2}$ \\
\hline
\end{tabular}


Table 4 shows that there are various intercepts among ten districts in West Kalimantan.

\subsection{Conclusions}

According to the results, it can be summarised that the positive contribution to GDP of Sanggau, Sintang, Sambas, Ketapang, Bengkayang, Landak, Singkawang, Kapuas Hulu, Melawi, and Sekadau is indicated by oil palm and rubber production. So that, even though there are some reports that claimed oil palm and rubber production giving negative impact to the environment, but the result of this research still shows that the two variables are statistically significant donating positive influence to increase the welfare of the inhabitants.

\section{Acknowledgement}

Authors would like to thank The Ministry Of Research, Technology and Higher Education of Indonesia for financial support in this research and the referees for the comments that greatly improved the manuscript. 


\section{References}

Ayunanda, M., \& Zain, I. (2014). Analisis Statistika Faktor yang Mempengaruhi Indeks Pembangunan Manusia di Kabupaten/Kota Provinsi Jawa Timur dengan Menggunakan Regresi Panel. Jurnal Sains dan Seni POMITS, 2(2), 237-242.

Baltagi, B.H. (2005). Econometric Analysis of Panel Data, Third Edition. The Atrium, John Wiley and Sons, Ltd, England.

BPS of West Kalimantan (2009-2015). Kalimantan Barat Dalam Angka. BPS Provinsi Kalimantan Barat. Pontianak.

BPS-Statistics Indonesia (2015). Statistik Indonesia 2015. BPS-Statistics Indonesia. Jakarta.

BPS-Statistics Indonesia (2017). Statistik Indonesia 2017. BPS-Statistics Indonesia. Jakarta.

BPS-Statistics Indonesia ${ }^{1}$ (2015). Statistik Kelapa Sawit Indonesia 2015. BPS-Statistics Indonesia. Jakarta

BPS-Statistics Indonesia (2016). Statistik Kelapa Sawit Indonesia 2016. BPS-Statistics Indonesia. Jakarta.

BPS-Statistics Indonesia ${ }^{1}$ (2016). Statistik Karet Indonesia 2016. BPS-Statistics Indonesia. Jakarta.

Hsiao, C. (2014). Analysis of Panel Data, Third Edition, Cambridge University Press, USA.

Feintrenie, L, et al. (2010). Why do Farmers Prefer Oil Palm? Lessons Learnt from Bungo District, Indonesia. Small-scale Forestry. 9(3), 379-396.

Fayissa, B. Et al. (2008). The Impact of Tourism on Economic Growth and Development in Africa. Tourism Economics, 14(4), 807-818.

Jaenicke, J, et al. (2010). Monitoring The Effect of Restoration Measures in Indonesian Peatlands by Radar Satellite Imagery, Journal of Environmental Management, 92, 630-638.

Mara, A \& Fitri, Y. (2013). Dampak Perkebunan Kelapa Sawit Rakyat Terhadap Pendapatan Wilayah Desa di Provinsi Jambi. Jurnal AGRISEP, 12(1), 109-121.

Nelonda S. (2008). Analisis Komoditas Karet Subsektor Perkebunan serta Pengaruhnya terhadap Pertumbuhan Sektor Pertanian di Provinsi Sumatera Barat. Jurnal Economac, 8(1).

Rist, L, Feintrenie, L, and Levang, P. (2010). The Livelihood Impacts of Oil Palm: Smallholders in Indonesia. Biodiversity and Conservation (Springer). 1009-1024.

Rosadi, D. (2011). Analisis Ekonometrika dan Runtun Waktu Terapan dengan R. CV Andi OFFSET, Yogyakarta.

Sanggin, S.E \& Mersat, N.I. (2012). Indigenous People's Participation in Land Development Project in Selected Areas of Sarawak. OIDA International Journal of Sustainable Development. 3(11), 67-80.

Sulistianingsih et al. (2017). Analysis of Palm Oil Production, Export, and Government Consumption to Gross Domestic Product of Five Districts in West Kalimantan by Panel Regression. Journal of Physics: Conference Series, 824(1).

Supriadi, W. (2013). Perkebunan Kelapa Sawit dan Kesejahteraan Masyarakat di Kabupaten Sambas. Jurnal Ekonomi Daerah, 1(1), 1-15.

The Ministry of Forestry of Indonesia, 2014, Statistik Kementrian Kehutanan Tahun 2013, Kementrian Kehutanan, Jakarta.

Wicke, B, et al, (2011). Exploring Land Use Changes and The Role of Palm Oil Production in Indonesia and Malaysia. Land Use Policy (Elsevier). 28, 193-206. 